\title{
Öğretmen Adaylarının Görüşlerine Göre Sözleşmeli Öğretmenlik Mülakatındaki Soruların incelenmesi ${ }^{1}$
}

\author{
Doç.Dr. Yılmaz TONBUL \\ Ege Üniversitesi-Türkiye \\ yilmaz.tonbul@ege.edu.tr
}

\author{
Yunus AĞAÇDiKEN(YL) \\ Ege Üniversitesi YL Öğrencisi-Türkiye \\ yunus.agacdiken@gmail.com
}

\begin{abstract}
Özet:
Bu araştırmanın amacı, öğretmen istihdamında mülakat uygulamasını ve uygulamadaki soruların niteliğini öğretmen adaylarının görüşleri üzerinden değerlendirmektir. Araştırma olgubilim deseninde yürütülmüş nitel verilere dayalı bir araştırmadır. Araştırmanın çalışma grubunu, 2016-2017 eğitim-öğretim yılında Ege Üniversitesi Eğitim Fakültesinin tüm bölümlerden son sınıf öğrencileri ve pedagojik sertifika programına katılan toplam 198 öğrenci oluşturmaktadır. Araştırmanın verileri, ulaşılan mülakat sorularından ve araştırmacılar tarafından geliştirilen yapılandırılmış görüşme formu aracılı̆ı ile toplanmıştır. Veriler, içerik analizi ile çözümlenmiştir. Bulgulara göre mülakat sorularında, "MEB Öğretmenlik Mesleği Genel Yeterlikleri" yeterince dikkate alınmamıștır. MEB Mülakat Değerlendirme Formu'nda yer alan değerlendirme ölçütleri, mülakat tekniği ile ölçülecek nitelikleri ölçmeye uygun bulunmamıştır. Öğretmen adayları, nitelikli öğretmenleri atamada, mülakatı gerekli bulmakla birlikte, atamada mülakatın katkı puanını yüksek bulmuştur. Uygulama, bu haliyle olumlu karşılanmamış ve sınava girecek adaylarda kaygıya yol açmıştır
\end{abstract}

Keywords: Mülakat, öğretmen istihdamı, ögretmen adayları

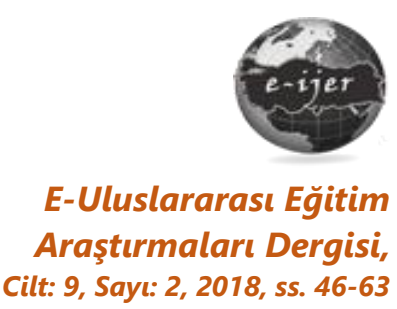

DOI: 10.19160/ijer.395554

\section{Önerilen Atıf}

Tonbul,Y. \&. Ağaçdiken, Y. (2018). Öğretmen Adaylarının Görüşlerine Göre Sözleşmeli Öğretmenlik Mülakatındaki Soruların İncelenmesi, E-Uluslararası Eğitim Araştırmaları Dergisi, Cilt: 9, Sayı: 2, 2018, ss. 46-63, DOI: 10.19160/ijer.395554

\footnotetext{
${ }^{1}$ 12. Uluslararası Eğitim Yönetimi Kongresinde (11-13 Mayıs 2017) bildiri olarak sunulmuştur.
} 


\section{GiRiş}

Öğretmen niteliğinin önemi, geçmişte ve günümüzde birçok araştırmacı tarafından dile getirilmektedir. Bursalıoğlu'na (1994) göre, okul olarak adlandırılan sosyal sistemin en stratejik parçalarından biri öğretmendir. Birçok araştırma bulgusu, eğitimin niteliğinin büyük ölçüde öğretmen niteliği ile doğru orantılı olduğunu (Celep, 2008); öğretmen niteliği ve öğretmen yeterliklerinin, öğrencilerin öğrenmelerini geliştirmede kilit noktasını oluşturduğunu (Yasseen, 2010); öğretmenlerin, sahip oldukları niteliklerin, öğrencilerin istenilen davranışları kazanmalarında etkili rol oynadığını (Toprakçı ve Altunay, 2015) göstermektedir. Bu bulgular, eğitim sisteminde öğretmenin taşıdığı önemi açıkça ortaya koymaktadır. Öğretmenin önemini pekiştiren etmenlerden birisinin de öğretmeninin etki alanının genişliği ve bu etkinin süresi olduğu söylenebilir. Şimşek (2003), öğretmenliğin siyasetçisinden doktoruna, mühendisinden polisine kısaca birçok meslek dalına insan gücü yetiştirmesi açısından toplumu tüm yönleriyle etkileme gücüne sahip mesleklerin başında geldiğini; bundan dolayı da belirli niteliklerle donanmış bireyler tarafından yerine getirilmesi gerektiğini belirtmektedir. Öğretmenliğin bir meslek olarak kabul edilmesi, standartlarının belirlenmesi, bu standartların kazandırılması ve söz konusu standartları karşılayan bireylerin atanması, mesleğin etki alanı düşünüldüğünde, kamusal alandan demokratik kitle örgütlerine kadar, tüm çevrelerin üzerinde duyarlılık gösterdikleri bir uygulama olarak öne çıkmaktadır. Tablo 1'de Cumhuriyetin ilanından günümüze kadar öğretmen yetiştirmeden sorumlu kurumlar ve öğretmenleri atama biçimleri verilmektedir.

\section{Tablo 1}

Cumhuriyet sonrası öğretmen yetiştiren kurumlar ve atama koşulları

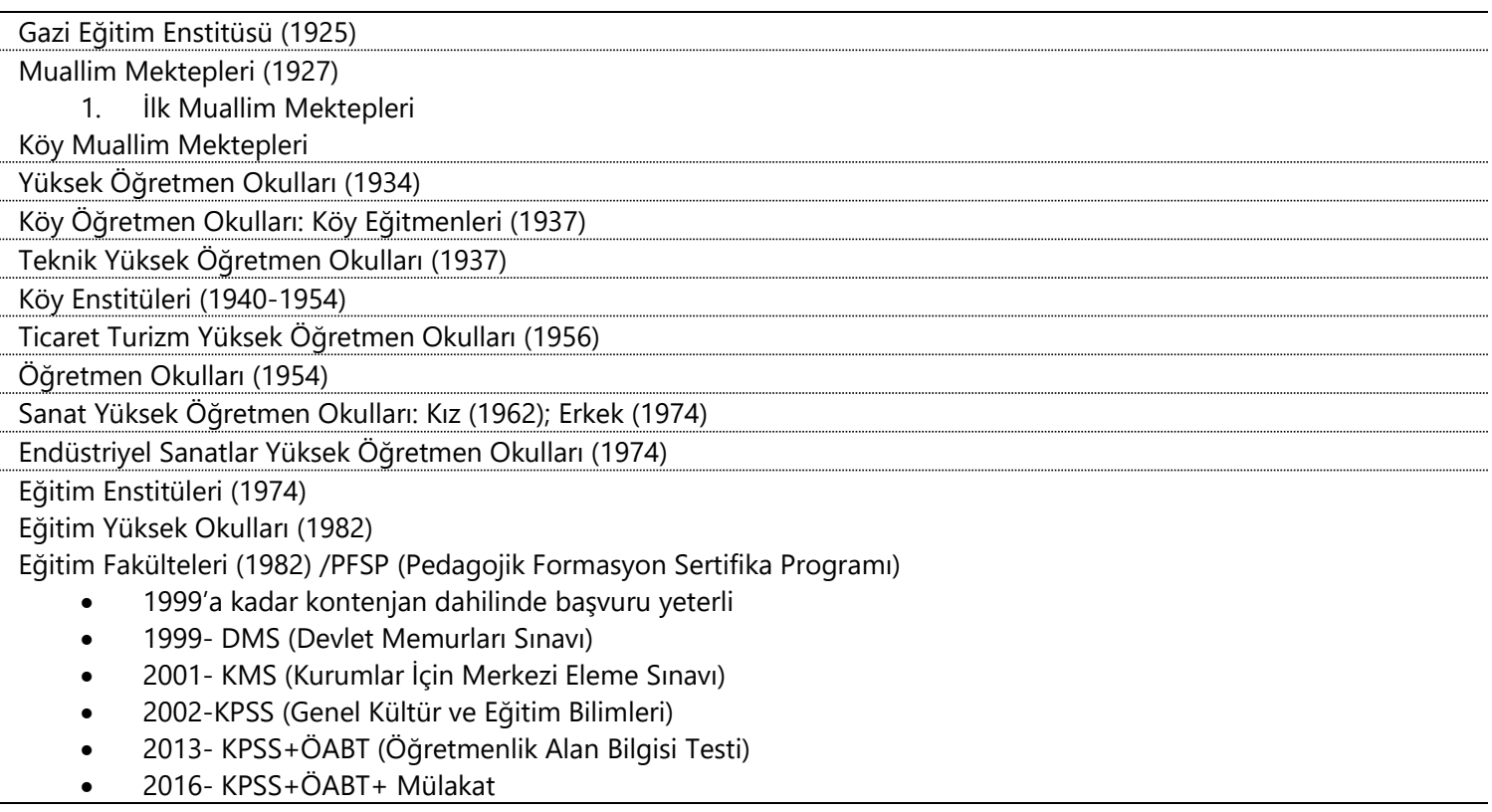

Tablo 1 incelendiğinde Cumhuriyet'in kuruluşu ile birlikte öğretmen yetiştirme arayışının hızlandığı, "fikri hür, vicdanı hür, irfanı hür" bir kuşak yetiştirmek için çocukların ve toplumun eğitimine önem verildiği, öğretmenliğin bir meslek olarak görüldüğü ${ }^{2}$ ve öğretmenlerin

\footnotetext{
213 Mart 1924 tarihli Orta Tedrisat Muallimleri Kanununun 1. maddesine göre öğretmenlik, “Devletin umumî hizmetlerinden talim ve terbiye vazifesini üzerine alan, müstakil sınıf ve derecelere ayrılan bir meslek" olarak tanımlanmıştır. 22 Mart 1926 tarihli ve 789 sayılı Maarif Teşkilâtına Dair Kanunun 12. maddesine göre de "maarif hizmetlerinde aslolan"ın öğretmenlik olduğu belirtilmiştir(Dursunoğlu, 2003).
} 
yetiştirilmesi işinin de bir uzmanlık gerektirdiği fikrinin oluştuğu anlaşılmaktadır. Tablodan da anlaşılacağı gibi öğretmenlerin atanmasında, mezun olmak dışında uzun bir süre herhangi bir koşul bulunmamakta zira ülkenin öğretmen gereksinimi ise üst düzeydedir. Dönemin eğitim bakanı Mustafa Necati Bey 22 Nisan 1926'da TBMM'de yaptığı konuşmada (Dursunluoğlu, 2003), 'ülkenin her yıl 3000 öğretmen ihtiyacını şu anki okulların karşılamaktan çok uzak olduğunu, bu yüzden okulların sayısının ivedilikle artırılmasını, bunun için özel idarelerin gelirlerinin \%10'unu bu işe ayırmaları amacıyla bir yasa teklifi verdiklerini' belirtmiştir. Dolayısıyla 1990'lı yıllara kadar öğretmen atamada merkezi ve aynı zamanda kitlesel bir seçme işlemi uygulanmamıştır. 1999 yılına kadar herhangi bir öğretmen yetiştiren kurumdan mezun olarak veya sonradan pedagojik formasyon sertifika programlarını tamamlayarak, hatta atandıktan sonra da hizmet içi eğitimler aracılığı ile de öğretmen olmanın mümkün olduğu anlaşılmaktadır.

1999 yılından itibaren, kamuda çalışmak isteyen öğretmenler de diğer devlet memurları gibi kitlesel anlamda ve merkezi olarak ilk kez sınava tabi tutuldular. Devlet Memurları Sınavı (DMS), iki yıl sonra 2001'de Kurumlar İçin Merkezi Eleme Sınavı (KMS) adıyla, 2002'den itibaren ise Kamu Personeli Seçme Sınavı (KPSS) adıyla, öğretmenlerin atanmak için başvurduğu sınavlar olarak uygulamaya konuldu. 2002 yılından beri genel kültür ve eğitim bilimleri testinden oluşan KPSS'ye, 2013 yılından itibaren Öğretmenlik Alan Bilgisi Testi (ÖABT) eklenmiştir. 2016 yılına gelindiğinde ise öğretmen istihdamında kadrolu personel alımı durdurulmuş, KPSS'nin ilgili puan türünden 50 puan ve üzeri alan adayların başvuru hakkına sahip olabileceği mülakat sınavı ile sözleşmeli öğretmen istihdamı yoluna gidilmiştir. Sözleşmeli öğretmenlik atama uygulaması, ilk olarak 2005 yılında uygulamaya konulmuşsa da, tüm öğretmen atama sistemini bağlayıcı nitelikte bir uygulama olmamıştır. Sözleşmeli istihdam modeli, özlük hakları açısından kadrolu öğretmenliğe göre dezavantajlı (kadroya geçme zorlukları, tayin haklarında kısıtlama, bazı okul türlerinde görevlendirilmeme, yönetici sınavlarına girememe) gibi görünmesine karşın, 2016 yılında ÖABT sınavına 311.759 kişi (ÖSYM, 2016) girmiştir. Her branş için taban puan barajını aşan toplam 36.876 (memurlar.net, 2017) aday mülakata çağrılmıştır. Bunlardan 14.873 aday (MEB İnsan Kaynakları, 2017) mülakatta başarılı sayılarak atanmıştır.

Eleman seçme ve yerleştirme araçlarından biri olan mülakatlar, amacına, yapılandırılma düzeylerine, hangi sektörde uygulandığına, kullanılan araçlara ve soruların niteliğine göre farklılık göstermektedir (Çetin ve Arslan, 2014). Personel istihdamında mülakatlar genel olarak birebir görüşmeler, panel grubu, çalışma arkadaşları grubu, sıralı görüşmeler, değerlendirme merkezi ve telefon görüşmeleri, sunum ve stres mülakatları biçiminde yapılabilmektedir (İnsan Kaynakları Yönetimi, 2017; Çetin, Arslan ve Dinç, 2015). Öğretmenlik mülakatında, birden fazla mülakat komisyonu üyesinin, her seferinde tek bir adaya, önceden belirlenmiş sorular üzerinden, adayın uygunluğunu belirlemek için toplu alımlarda işe koşulan bir mülakat türü olan panel grubu mülakatı uygulanmıştır. Mülakat süresince yapılandırılmış soruların yanı sıra, zaman zaman mülakatın akışı gereği adayı yakından tanımak, adaydan yanıtları ayrıntılandırmasını veya örnek vermesini istemek hatta adayı rahatlatmak amaçlı yapılandırılmamış, sohbet tarzı sorular da sorulabilmektedir. Bu tür mülakatlara karma mülakat da denmektedir. Anderson (2003), personel istihdamında yeni teknolojilerin sunduğu olanaklar sayesinde telefon ya da video uygulamalı mülakatlardan yararlanıldığını; ayrıca sanal ortamda gerçek sınıf ortamlarından oluşturulan senaryolar üzerinden de mülakatların kullanıldığını belirtmektedir.

Mülakat uygulamalarının bir araç olduğu dikkate alındığında, mülakatın türü kadar mülakatta neyin ölçüleceği konusu da önem taşımaktadır. MEB tarafından Öğretmenlik Mesleği Genel Yeterlikleri (2006) adı altında geliştirilen öğretmen yeterlikleri, 6 yeterlik alanı, 31 alt yeterlik ve 233 performans göstergesinden oluşmaktadır. Söz konusu yeterlik alanlarının bir bölümü KPSS'de genel kültür (Tarih, Coğrafya, Edebiyat, güncel konular vb.), eğitim bilimleri (program geliştirme, öğrenme-öğretme teknikleri ve ilkeleri vb.) ve alan bilgisi soruları üzerinden yoklanmaktadır. Öğretmenlik Mesleği Genel Yeterlikleri metninde yer alan ancak test tekniği ile ölçülmesi uygun olmayan kişisel ve mesleki değerler, iletişim becerileri, özgüven vb. konu alanları için mülakatın daha uygun olduğu düşünülebilir. Shechtman (1992) öğretmenlerin sınıf 
içi performanslarını etkileyen önemli değişkenler olan sözel anlatım becerisi, kişilik özellikleri ve liderlik becerileri gibi duyuşsal ve psikomotor boyutları kapsayan değişkenlerin olduğunu belirtmiştir. Shechtman ve Godfried (1993) ve Byrnes, Kiger ve Shechtman ise (2003) öğretmen adaylarının psikomotor ve duyuşsal davranışlarının ölçülmesini temele alan grup odaklı bir değerlendirme türü olarak mülakattan aldıkları puanların, sınıf içi öğretim performanslarını, akademik ölçütlerden daha iyi kestirdiğini bulmuşlardır. Bu bağlamda öğretmen adaylarının öğretmen yetiştirme programlarına girişte psikomotor ve duyuşsal davranışlarının ölçülmesi gerekliliği doğmuştur. Demirel (1992) öğretmen yetiştirmeyi sistem yaklaşımına göre ele almakta ve sistemin girdisi olan öğretmen adaylarının duyuşsal ve psikomotor giriş davranışlarının mülakat teknikleri ile ölçülmesini önermektedir. Bu noktada ölçülecek bilişsel, duyuşsal ve devinişsel nitelikleri açıkça ortaya koymak kadar, soru türlerini ve soruların hangi sıralamaya göre sorulacağını belirlemek de önem kazanmaktadır. Bilişsel alan sorularında Bloom taksonomisi dikkate alındığında, mülakatların analiz, sentez ve yaratıcılık basamaklarına yönelik sorular sormaya uygun olduğu; duyuşsal alanı ölçmeye yönelik soruların değer verme, örgütleme ve kişilik haline getirme basamaklarındaki kazanımları ölçmeyi kolaylaştırdığı ve devinişsel alanla ilgili de beceri ve yaratma basamaklarını ölçmeye yönelik soruların mülakatlarda daha öne çıkması gerektiği söylenebilir. Alanyazında mülakatlarda farklı soru türlerine yer verilmesi gerektiği belirtilmektedir. Buz kıııcı ve temel sorular, davranış, etik uygunluk, yetkinlik, zeka ve kapanış soruları (Kador, 2016) ya da varsayımsal, yetenek, motivasyon, kariyer, ilgi sorularının (Armstrong ve Taylor, 2014) gibi farklı soru türlerinin mülakat komisyonu üyeleri tarafından etkili kullanılması, mülakatın geçerliliği konusunda etkili olacaktır. Dolayısıyla sınav komisyonu üyelerinin uzmanlık alanlarının, soru sormak kadar dinleme ve beden dilini kullanma becerilerinin; mülakat değerlendirme yöntemlerine ne kadar vakıf olduklarının; iyi öğretmen kimdir ve nasıl seçilmelidir sorularına verecekleri yanıtların da, mülakatların amacına uygun yürütülmesinde etkili olacağı söylenebilir.

Mülakatlar, başta özel sektör olmak üzere kamunun bazı alanlarında da uzun zamandır personel seçiminde kullanılan başlıca yöntem olmuştur. Özellikle yapılandırılmış mülakat yönteminin, informal işlemlerde daha iyi olduğu ancak mülakatta kullanılacak puanlamanın, araştırma sonuçları ile geliştirilmesi gerektiği belirtilmektedir (Muller, 1981; Pellicer, 1981). $A B D$ 'de eyaletten eyalete farklılıklar olmasına rağmen bireysel ve grup mülakatlarının giriş sınavında kullanılması birçok programda uygulanmaktadır (George ve Kathryne, 1996). New Jersey de Montclair State Üniversitesi'nde öğretmen adayları, sekiz değişken açısından yeterli bulunduktan sonra eğitim fakültesine alınmaktadırlar. Bu değişkenler öğretmen adaylarının konu alanı bilgisi, öğretme sorumluluğu, kişisel nitelikler, yazılı iletişim, sözlü iletişim ve mülakat heyetinin genel kişisel ve mesleki yargılarını kapsamaktadır. Bu sekiz değişkenin ölçülmesi, bireysel mülakat tekniği ve yazılı sınav ile yapılmaktadır (Jacobowitz, Delorenzo ve Adirim, 2000). İngiltere'de eğitim fakültelerine öğrenci seçimi yapılırken öğrenciler mülakata alınmaktadır. Bu mülakatta öğrencilerin fiziksel ve zihinsel olarak öğretmenlik mesleğine uygun olup olmadıklarına karar verilir. Bu komisyonlarda, deneyimli öğretmenler de jüri üyesi olarak görev yapmaktadır (EURYDICE, 2006). Ülkemizde ilk kez gerçekleştirilen bu uygulama için il/illçe Milli Eğitim Müdürlükleri'nin görevlendireceği kişilerin başkanlığında, beş kişiden oluşan heyetler kurulmuştur. Heyette yer alacak üyeler, deneyimli eğitim-öğretim elemanı olmak üzere il/ilçe Milli Eğitim Müdürlükleri tarafından MEB'e önerilen kişilerden oluşmuştur. Her adayın mülakat puanı, MEB Mülakat Değerlendirme Formu'nda (2016) yer alan bir konuyu kavrayıp özetleme, ifade yeteneği ve muhakeme gücü, iletişim becerileri, özgüveni ve ikna kabiliyeti, bilimsel ve teknolojik gelişmelere açıklığı ve topluluk önünde temsil yeteneği ve eğitimcilik nitelikleri boyutları, mülakat heyeti üyelerince 1 ile 5 arasındaki bir tam sayıyla puanlanması sonucunda, tüm üyelerin verdiği puanların ortalamaları alınarak hesaplanmıştır.

Alanyazın incelendiğinde, mülakat sınavının öğretmen adaylarının seçiminde kullanılmasını, öğretmenlerin, öğretmen adaylarının ve öğretim elemanlarının önerdikleri görülmektedir ( Bayrak; 1990; Senemoğlu, 2003; Türkoğlu, 1988). Okçabol (2004), olumsuz kişilik 
özelliklerine sahip olanları, öğretmenlik mesleği (özellikle ilköğretim alanları) dışında tutacak bir sürecin oluşturulamadığını belirtirken; 17. Milli Eğitim Şurası'nda da öğretmen adaylarının istihdamında, akademik başarının yanı sıra öğretmenlik mesleğinin gerektirdiği kişisel niteliklerin ölçülmesine ve değerlendirmesine yönelik mekanizmaların oluşturulması ve bu kapsamda, öğretmenlik programlarına girişteki seçme sürecinin yeniden gözden geçirilmesi (MEB şura kararları, 2010) kararı alınmıştır. Ancak sözleşmeli öğretmenlik mülakatı ile ilgili sosyal medyaya yansıyan haberler incelendiğinde sendikaların sözleşmeli mülakat uygulamasına karşı çıkma konusunda görüş birliği içerisinde oldukları anlaşıımaktadır (Eğitim Bir-Sen, 2016; Ülkar, 2017). Yine basın yayın organlarına (Sağlar, 2016; Güçlü, 2016) yansıyan haberler incelendiğinde, 2016 yılında ilk kez gerçekleştirilen bu uygulamaya karşı, çok sayıda olumsuz görüşün de gündeme geldiği anlaşılmaktadır. Getzels ve Guba'nın (1957) sosyal sistem kuramı, çalışanların performansını etkilemede roller ve beklentilerden oluşan örgütsel boyut ile kişilikler ve gereksinimlerden oluşan bireysel boyutun örtüştürülmesi gerektiğini ortaya koymaktadır. Çalışanların güdülenmesinde süreç kuramları başlığı altında toplanan öz yeterlik kuramı, beklenti kuramı, eşitlik kuramı, hedef belirleme gibi kuramlar bulunmaktadır (Hoy ve Miskel, 2001). Bu kuramlar ışığında, Milli Eğitim Bakanlığıının beklentileri ile öğretmen adaylarının öz yeterlik algıları, öğretmenlik mesleğine yükledikleri anlam, geleceğe yönelik hedefleri ile atanacak öğretmen adaylarını belirlemede işe koşulan mülakat uygulamalarını nasıl değerlendirildiği konularına açıklık getirilmesi gerekmektedir.

Öğretmenin eğitim sistemindeki rolü ve onlara yüklenen sorumluluklar düşünüldüğünde, mülakat sınavının profesyonel biçimde ve amacına uygun yürütülmesi oldukça önem arz etmektedir. Uygulamanın henüz yeni olmasından dolayı ülkemizde bir alanyazın oluşmamıştır. Bu çalışma, mülakat uygulamasında karşılaşılan sorunları ortaya koyarak, alanyazına ve bundan sonraki uygulamalara ışık tutmayı amaçlamaktadır. Bu doğrultuda aşağıdaki sorulara yanıt aranmıştır;

1- Mülakat soruları, 'MEB Öğretmen Yeterliklerinde' ve 'MEB Mülakat Değerlendirme Formu'nda aranan ölçütlere göre nasıl bir dağılım göstermektedir?

2- Mülakat uygulamasının (a) gerekliliğine; (b) hangi yeterliklerin ölçülmesi gerektiğine; (c) KPSS puanının ve mülakat puanlarının atamada etkisine (d) Mülakatın adaylar üzerindeki etkisi ve sürece nasıl hazırlandıklarına ve (e) öğretmen istihdamında mevcut uygulamalar dışında hangi uygulamalara yer verilmesi gerektiğine ilişkin katılımcı görüşleri nasıl bir dağılım göstermektedir?

3- Öğretmenlik mülakat uygulamasına ilişkin katılımcıların geliştirdikleri metaforlar temalarına göre nasıl bir dağılım göstermektedir?

\section{YÖNTEM}

\section{Araştırma modeli:}

Bu araştırmada mülakat uygulaması, çıkmış sorular üzerinden öğretmen yeterlikleri ve mülakatta aranan niteliklerle, sınava yeni girecek olan öğretmen adaylarının, uygulamayı nasıl anlamlandırdıkları sorularına yanıt aranmıştır. Bundan dolayı, araştırmada nitel araştırma desenlerinden olgubilim deseninden yararlanılmıştır. Olgu bilim deseni farkında olduğumuz, ancak derinlemesine ve ayrıntılı bir anlayışa sahip olmadığımız olgulara odaklanmaktadır (Yıldırım ve Şimşek, 2016).

\section{Çalışma grubu:}

$\mathrm{Bu}$ araştırmanın çalışma grubu amaçlı örnekleme yöntemlerinden kolay ulaşılabilir durum örneklemesi ve ölçüt örnekleme kullanılarak belirlenmiştir. Patten'e (2010) göre, olasılık temelli 
örnekleme temsiliyeti sağlamak yoluyla geçerli genellemeler yapma konusunda önemli avantajlar sağlarken, amaçlı örnekleme zengin bilgiye sahip olduğu düşünülen durumların derinlemesine çalışılmasına olanak vermektedir.

Araştırmanın çalışma grubunu, 2016-2017 eğitim-öğretim yılında Ege Üniversitesi Eğitim Fakültesi Bilgisayar ve Öğretim Teknolojileri Eğitimi, Fen Bilimleri Öğretmenliği, Okul Öncesi, PDR Bölümü Öğretmenliği, Türkçe Öğretmenliği ve Psikolojik Danışmanlık ve Rehberlik bölümü son sınıf öğrencisi toplam 114 öğrenci ile Pedagojik Formasyon Programına devam eden Matematik, Fizik, Kimya, Biyoloji, Beden Eğitimi, İngilizce Öğretmenliği, Türk Dili ve Edebiyatı, Coğrafya bölümlerinden olmak üzere 84 öğrenci (toplam 198 öğrenci), oluşturmaktadır. Öğrenciler için Ö1, Ö2, Ö3, Ö4 ve Ö5 gibi, derlenen sorular için de S1, S2, S3, S4 ve S5 vb. biçiminde kodlama yapılmıştır.

\section{Veri toplama aracı ve analizler:}

Araştırmada veri analizinde kullanılan sorular, sosyal paylaşım sitesi Facebook üzerinde sözleşmeli öğretmenlik soru paylaşım gruplarının paylaştıkları sorulardan, dershanelerin yayımladıkları mülakat sorularından, çıkmış mülakat soruları ile ilgili basılı yayınlardan derlenmiştir. Soruların analizinde 'Öğretmenlik Mesleği Genel Yeterlikleri' maddeleri ve 'MEB Mülakat Değerlendirme Formu' ölçütleri dikkate alınmıştır. Içcrik çözümlemesi her iki araştırmacı tarafından ayrı yapılmış, başka bir araştırmacıya daha verilerek, kodlayıcılar arasındaki uyum yüzdesi artııımaya çalışılmıştır.

Katılımcılara yönelik veriler 'Sözleşmeli Öğretmenlik Mülakatı Uygulamasına ilişsin Aday Öğretmenlerin Görüşleri' adlı anket ile elde edilmiş ve veriler içerik analizine tabi tutulmuştur. Anketin geliştirilmesi sürecinde, yeni bir uygulamaya giderken Drucker (Swaim, 2011) ile Everard ve Morris'in (Çınar, 2005) değişim yönetimi ilkeleri; yeni uygulamaları hayata geçirmenin kuramsal çerçevesi ile ilgili olarak Özümseme Kuramı, Gündem Belirleme Kuramı, Yeniliklerin Yayılımı Kuramı (Miles, 2016) gibi kuramlar dikkate alınmıştır. Eğitim fakültesi son sınıfta okuyan 5 öğrenci, sınava katılan 3 öğretmen adayı ve sınav komisyonlarında yer alan 2 okul yöneticisi ile ön görüşme yapılarak anketin geliştirilmesinde bu görüşlerden yararlanılmıştır. Personel istihdamında bir araç olarak mülakat uygulamasını ele alan farklı kaynaklar incelenmiştir (Çetin ve Arslan, 2014; Insan Kaynakları Yönetimi, 2017; Erkan ve Erdoğan, 2017). Araştırmanın veri toplama aracı, açık uçlu soruların yanı sıra, katılımcıların sıralama yapabilecekleri sorulardan ve bir metafor sorusundan oluşmaktadır. Anket maddelerindeki açık uçlu sorulara iki örnek olarak şunlar verilebilir: 'Öğretmen atamasında, nitelikli öğretmenlerin seçimi için mülakat uygulaması sizce gerekli midir? Niçin?'; Önümüzdeki yıl mülakata girebilecek olmanız sizi nasıl hissettiriyor?' Öğretmen istihdamında mülakat uygulamasını bir nesneye, canlıya, bitkiye, kişiye ya da herhangi bir şeye benzetmeniz istense neye benzetirdiniz? Niçin? Gerek açık uçlu sorulara gerekse metafor sorusuna verilen yanıtlar, iki araştırmacı tarafından ayrı ayrı içerik analizine tabi tutulmuş, ayrıca nitel analiz konusunda deneyimli bir doktora öğrencisi ile paylaşılmış ve üç değerlendiriciden en az ikisinin mutabık kaldığı tema-alt tema ve metaforlar, analize dâhil edilmiştir. Böylece, araştırmanın iç güvenirliği (tutarlııı) sağlanmaya çalışılmıştır. Araştırmada, mülakatlarda çıkmış sorulara, birçok bölümden öğretmen adayının görüşlerine ve metaforlara yer verilerek, veri ve katııımcı çeşitliliği sağlanmaya çalışımıştır. Katılımcı görüşlerinden doğrudan alıntılar yapılmış, verilen yanıtların kaynağına inilmeye çalışılmışır. Alanyazında, uzman görüşü alma, doğrudan alıntılara yer verme, çeşitleme yoluna gitme, birden fazla araştırmacıyı dahil etme ile araştırmanın güvenirliğinin artırılabileceği vurgulanmaktadır (Glesne ve Peshkin, 1992; Shenton, 2004; Yıldııım ve Şimşek, 2016). 


\section{BULGULAR}

Araştırmanın birinci alt problemi 'Mülakat soruları, MEB Öğretmen Yeterlikleri ve MEB Mülakat Değerlendirme Formu'nda aranan ölçütlere göre nasıl bir dağılım göstermektedir?' biçiminde idi. Bulgular Tablo 2'de ve Tablo 3'te verilmektedir.

Tablo 2:

Soruların MEB Ögrretmen Yeterliklerine Göre Dağılımı

\begin{tabular}{|c|c|}
\hline Öğretmen Yeterlilikleri & Çıkmış sorular \\
\hline A.Kişisel ve Meslekî & Resmi yazı tebliğ süresi kaç gündür? \\
\hline Değerler - Meslekî & EBA ve FATIH projelerinin açılımı nedir? \\
\hline $\begin{array}{l}\text { Gelişim } \\
(\mathrm{f}=38 ; \% 31,1\end{array}$ & $\begin{array}{l}\text { Beyin göçünü engellemek için neler yapılabilir? } \\
\text { Örgün ve Yaygın eğitim kurumlarının bir arada olduğu eğitim } \\
\text { kampüslerinin verimliliğinin artııııması için neler yapılabilir? } \\
\text { Eğitimde sürekliliği sağlamak için neler yapılabilir? }\end{array}$ \\
\hline $\begin{array}{l}\text { B. Öğrenciyi Tanıma } \\
(\mathrm{f}=8 ; \% 6,5)\end{array}$ & $\begin{array}{l}\text { Öğrencileri ilgi yetenek becerilerine göre yönlendirmenin önemi } \\
\text { nedir? } \\
\text { Öğrencilerinizin bilişsel ve devinişsel özelliklerini bilmeniz } \\
\text { öğretim sürecinde size ne gibi avantajlar sağlar? } \\
\text { Öğretmen olduğunuzda alanınızla ilgili öğrencilerinize } \\
\text { önerebileceğiniz itaplar nelerdir? }\end{array}$ \\
\hline $\begin{array}{l}\text { C.Öğretme ve Öğrenme } \\
\text { Süreci } \\
(\mathrm{f}=15 ; \% 12,5)\end{array}$ & $\begin{array}{l}\text { Genital dönemdeki (12 yaş) çocuklara nasıl etkinlikler } \\
\text { planlarsınız? } \\
\text { Öğrencilere dersi anlattınız ama seviyeleri düşük ve anlamadılar. } \\
\text { Nasıl bir yol izlersiniz? } \\
\text { Eğitimde videonun olumlu ve olumsuz etkileri nelerdir? }\end{array}$ \\
\hline $\begin{array}{l}\text { D.Öğrenmeyi, Gelişimi } \\
\text { İzleme ve Değerlendirme } \\
(\mathrm{f}=4 \% 3,2)\end{array}$ & $\begin{array}{l}\text { Bilgisayarın ölçme ve değerlendirmede ve de izleme yeri nedir? } \\
\text { Olumlu ve olumsuz etkilerini açıklayın. } \\
\text { Kazanım kavrama testleri hakkında ne düşünüyorsunuz? }\end{array}$ \\
\hline $\begin{array}{l}\text { E.Okul, Aile ve Toplum } \\
\text { Illişkileri } \\
(\mathrm{f}=4 ; \% 3,2)\end{array}$ & $\begin{array}{l}\text { Ebeveyn olarak çocuğunuzun nasıl insanlarla arkadaş olmasını } \\
\text { ya da olmamasını istersiniz, nasıl engellersiniz? } \\
\text { Cocuk yetiştirmede ailenin görevi nedir? }\end{array}$ \\
\hline $\begin{array}{l}\text { F.Program ve İçerik } \\
\text { Bilgisi } \\
(\mathrm{f}=33 ; \% 27)\end{array}$ & $\begin{array}{l}\text { Yaygın eğitim ile örgün eğitim arasındaki fark nedir? } \\
\text { Biyolojik olarak aklın önemi nedir? } \\
\text { Yapılandırmacı eğitim nedir? } \\
\text { Sistematik bilim, bilimsel bilgi ve felsefi bilgi nedir? }\end{array}$ \\
\hline $\begin{array}{l}\text { Belirsizlik Taşıyan Sorular } \\
(\mathrm{f}=17 ; \% 13,9)\end{array}$ & $\begin{array}{l}\text { Vahabilik hakkında ne düşünüyorsun? } \\
15 \text { Temmuz gecesi neredeydiniz? } \\
\text { Üniversitede nerede kaldın ve kendini nasıl finanse ettin? } \\
\text { Hangi gazete ve köşe yazarlarını takip ediyorsunuz? }\end{array}$ \\
\hline
\end{tabular}

Tablo 2 incelendiğinde en fazla sorunun 'Kişisel ve Meslekî Değerler - Meslekî Gelişim' yeterlilik alanından çıktığı $(\% 31,1)$, bunu 'Program ve İçerik Bilgisi' (\%27) ve 'Öğretme ve Öğrenme Süreci' $(\% 12,5)$ yeterlik alanlarının izlediği görülmektedir. Öğretmen yeterlikleri boyutlarından herhangi birine dâhil edilemeyen sorular ise, 'Belirsizlik Taşıyan Sorular'(\%13,9) başlığı altında verilmiştir.

Soruların MEB tarafından duyurulan mülakat değerlendirme ölçütlerine göre dağılımı için yapılan analizler Tablo 3'te verilmektedir. 


\section{Tablo 3:}

Soruların MEB mülakat değerlendirme ölçütlerine göre dağılımı

\begin{tabular}{|c|c|c|}
\hline Soru Örnekleri & $\begin{array}{l}\text { Mülakat Değerlendirme } \\
\text { Ölçütleri }\end{array}$ & $\begin{array}{l}\text { Soru ölçüt } \\
\text { ilişkisi }\end{array}$ \\
\hline $\begin{array}{l}\text { Gelir düzeyi yüksek ve gelir düzeyi düşük aileden gelen } \\
\text { öğrenci arasındaki fark eğitime nasıl yansır? }\end{array}$ & \multirow{2}{*}{$\begin{array}{l}\text { 1. Bir konuyu kavrayıp } \\
\text { özetleme, ifade yeteneği ve } \\
\text { muhakeme gücü. }\end{array}$} & 1,2 \\
\hline $\begin{array}{l}\text { Sistematik bilgi, felsefi bilgi ve bilimsel bilgi eğitime nasıl } \\
\text { yansır? }\end{array}$ & & 1,2 \\
\hline Sınıf içi disiplin sorunu yaşarsanız bunu nasıl önlersiniz? & \multirow{2}{*}{$\begin{array}{l}\text { 2. İletişim becerileri, özgüveni } \\
\text { ve ikna kabiliyeti. }\end{array}$} & 1,2 \\
\hline $\begin{array}{l}\text { Öğrencilere dersi anlattınız ama seviyeleri düşük ve } \\
\text { anlamadılar. Nasıl bir yol izlersiniz? }\end{array}$ & & 1,2 \\
\hline Eğitimde pekiştireç gerekli midir? Niçin? & \multirow{2}{*}{$\begin{array}{l}\text { 3. Bilimsel ve teknolojik } \\
\text { gelişmelere açıklığı. }\end{array}$} & 1,2 \\
\hline $\begin{array}{l}\text { Teknolojinin eğitimde olumsuz olduğu tezini nasıl } \\
\text { çürütürsün? }\end{array}$ & & $1,2,3$ \\
\hline $\begin{array}{l}\text { Öğrencilerin kitaplardan öğrendikleri bilgiler mi yoksa } \\
\text { internet üzerinden edindikleri bilgiler mi daha güvenilirdir? }\end{array}$ & \multirow[t]{3}{*}{$\begin{array}{l}\text { 4. Topluluk önünde temsil } \\
\text { yeteneği ve eğitimcilik nitelikleri. }\end{array}$} & $1,2,3$ \\
\hline Eğitim teknolojilerinin dersler için yararı nedir? & & $1,2,3$ \\
\hline İyi bir öğretmende olması gereken özellikler nelerdir? & & $1,2,4$ \\
\hline
\end{tabular}

Tablo 3 incelendiğinde sorulan soruların birden fazla mülakat değerlendirme ölçütü altında sınıflanabileceği, dolayısıyla iç içe geçtiği görülmektedir. Aslında her soruya verilen yanıt, doğal olarak (1) Bir konuyu kavrayıp özetleme, ifade yeteneği muhakeme gücü ve (2) İletişim becerileri, özgüveni ve ikna kabiliyeti değerlendirme ölçütü altında sınıflanmakta, hatta (4)Topluluk önünde temsil yeteneği ve eğitimcilik nitelikleri ölçütü de her soruda, gerek adayın gözlemlenmesi sonucunda gerekse verilen yanıtların içeriği açısından aynı anda devreye girmektedir. Dolayısıyla bu ölçütlerin ayırt ediciliğinin olduğunu söylemek oldukça güç görünmektedir. Tablo 4'te mülakat uygulamasının gerekliliğine ilişkin öğrenci görüşlerinin dağılımı verilmektedir.

\section{Tablo 4:}

Mülakat uygulamasının gerekliliğine ilişkin öğrenci görüşlerinin dağılımı

\begin{tabular}{|c|c|}
\hline Tema & Öğrenci Görüşü \\
\hline $\begin{array}{l}\text { Tamamlayıcı bir } \\
\text { nitelik taşıma (Koşullu } \\
\text { onay) } \\
\text { (f=131, \%66,17) }\end{array}$ & $\begin{array}{l}\text { Ö96:Son aşama sınavı olarak uygulanması doğru ancak atama üzerinde makul oranda } \\
\text { tamamlayıcı olması doğrudur. } \\
\text { Ö5:Mülakat } 4 \text { yıllık eğitimin hemen sonunda olmalıdır. Çocuklara ifade etme biçimimizin } \\
\text { ve sahip olduğumuz yeterliliklerin bu aşamada incelenmesi faydalı olacaktır. } \\
\text { Ö11:Olmalı ancak, mülakatlar öğretmenlerin ders anlatma gibi yeterliliklerini ölçmelidir. } \\
\text { Öğretmen için önemli olan bilgiyi öğrenciye nasıl aktardığıdır. }\end{array}$ \\
\hline $\begin{array}{l}\text { Kaygı, önyargı, } \\
\text { güvensizlik } \\
\text { (Yapılmasın) } \\
(f=67, \% 33,83)\end{array}$ & $\begin{array}{l}\text { Ö171: Hayır yapılmasın. Çünkü mülakat uygulamasının komisyonun inisiyatifine göre } \\
\text { sonuçlandığını düşünüyorum. Ayrıca böyle bir uygulamanın 5-10 dakika içinde } \\
\text { öğretmenin gerekli niteliklerine sahip olup olmadığını tespit edeceğine inanmıyorum. } \\
\text { Ö6:KPSS ve Alan sınavı bence yeterli, mülakatta herkesin hakkı yendiği için bence gerek } \\
\text { yok. } \\
\text { Ö9:Bence olmamalıdır. Çünkü adil davranıldı̆ı̆ın düşünmüyorum. Komisyon üyelerinin } \\
\text { bile aynı farklı puanlaması mümkünken farklı illerde farklı komisyon üyeleri farklı } \\
\text { değerlendirmeler yaparak birçok insanın kaderiyle oynanabiliyor. }\end{array}$ \\
\hline
\end{tabular}


Tablo 4 incelendiğinde, katılımcıların üçte ikisinin, (\%66), mülakatların yapılmasını koşullu olarak onayladıklarını, gerekçe olarak, iletişim ve öğretim becerileri gibi niteliklerin mülakatla ölçülebileceğini ancak mülakatın tek başına belirleyici olmaktan çok, diğer puanlama türlerine tamamlayıcı bir etki yapması gerektiği yönünde açıklamalar yapmışlardır. Yapılmaması yönünde görüş belirtenler ise $(\% 33,83)$, komisyon üyelerinin niteliği ve sürenin kısalığının, öte yandan amacın dışına taşan tarafgir davranışların, mülakatların amacına hizmet etmediği gibi gerekçeler ileri sürmüşlerdir.

\section{Tablo 5:}

Mülakatlarda ölçülmesi önerilen yeterliklere ilişkin öğrenci görüşleri

\begin{tabular}{|c|c|c|c|}
\hline Tema & & $\mathbf{F}$ & $\%$ \\
\hline Eğitim & $\begin{array}{ll}\text { - } & \text { Sinıf yönetimi (72) } \\
\text { - } & \text { Öğretim yöntem ve tekn.(69) } \\
\text { - } & \text { Liderlik (63) } \\
\text { - } & \text { Eğitim yönetimi (62) } \\
\text { - } & \text { Program geliştirme (61) } \\
\text { - } & \text { Ölçme (58) }\end{array}$ & 385 & 42,1 \\
\hline İletişim & $\begin{array}{l}\text { eri } \\
\text { Etkili konuşma ve kendini düzgün ifade edebilme (102) } \\
\text { İna yeteneği (54) } \\
\text { Seviyeye uygun davranabilme (48) } \\
\text { Beden dilini etkili kullanma (46) } \\
\text { Kolay iletişim kurabilme (42) } \\
\text { Uygun tepki verebilme (41) } \\
\text { Dikkat çekme (38) }\end{array}$ & 371 & 40,4 \\
\hline \multicolumn{2}{|c|}{ Özel Alan Bilgisi (85) } & 85 & 9,3 \\
\hline $\begin{array}{r}\text { Genel } \\
\checkmark \\
\checkmark \\
\checkmark\end{array}$ & $\begin{array}{l}\text { er (15) } \\
\text { la çeşitliliği (10) } \\
\text { tı zenginliği (8) }\end{array}$ & 33 & 3,8 \\
\hline $\begin{array}{c}\text { Psikoloj } \\
\checkmark \\
\checkmark\end{array}$ & $\begin{array}{l}\text { kler } \\
\text { ojik sağlık (24) } \\
\text { ven (4) }\end{array}$ & 28 & 3,5 \\
\hline $\begin{array}{c}\text { Problen } \\
\checkmark \\
\checkmark\end{array}$ & $\begin{array}{l}\text { Sorunları baş edebilme kapasitesi (6) } \\
\text { Yaratıcı çözümler geliştirme (3) }\end{array}$ & 9 & 0,9 \\
\hline \multicolumn{2}{|c|}{ Staj Deneyimi (Tecrübe) (4) } & 4 & 0,4 \\
\hline & Toplam & 915 & 100 \\
\hline
\end{tabular}

Tablo 5'te öğretmen adaylarının mülakatta en çok yoklanmasını istedikleri mesleki yeterliklerin eğitim bilimleri (\% 42,1), iletişim (\% 40,4) ve alan bilgisi $(\% 9,3)$ temalarında toplandığı görülmektedir. Diğerlerine göre az sayıda da olsa genel kültür $(\% 3,8)$ ve psikolojik özellikler de $(\% 3,5)$ vurgulanmıştır.

Tablo 6:

KPSS ve mülakat puanlarının atamada oranının ne kadar olması gerektiğine ilişkin öğrenci görüşleri

\begin{tabular}{lcc}
\hline Atama Puanı Oranı & $\mathbf{f}$ & \% \\
\hline KPSS\%-70 - Mülakat \% 30 & 99 & 50,1 \\
KPSS\%90 - Mülakat \% 10 & 44 & 22,23 \\
KPSS\%85 - Mülakat \% 15 & 36 & 18,17 \\
KPSS\% $40-$ Mülakat \% 60 & 19 & 9,50 \\
\hline Toplam & $\mathbf{1 9 8}$ & $\mathbf{1 0 0}$
\end{tabular}


Tablo 6'ya göre katılımcıların büyük çoğunluğu (\% 90,5) mülakatın, KPSS puanına göre daha düşük değerlendirilmesi gerektiğini; önemli bir kısmının, mülakatın sınav sonucuna etkisinin \%30'u geçmemesi gerektiği yönünde görüş bildirdiği görülmektedir.

Tablo 7:

Gelecek yıl mülakata girecek olmalarının onları nasıl hissettirdiğine ilişkin katılımcı görüşlerinin dağılımı

\begin{tabular}{|c|c|}
\hline Tema & Doğrudan Alıntılar \\
\hline $\begin{array}{l}\text { 1) Olumlu (\%9) } \\
\text { - Iyimser olma, } \\
\text { - Umutlu olma vb. }\end{array}$ & $\begin{array}{l}\text { Ö78:Mesleğe olan hevesimden ötürü beklentim olumlu yönde. } \\
\text { Ö129: Açıkçası heyecanlı değilim, bu mesleği seviyorum, elimden geleni yapacağımı } \\
\text { düşünüyorum. }\end{array}$ \\
\hline $\begin{array}{l}\text { 2) Olumsuz (\%91) } \\
\text { - Tedirginlik }\end{array}$ & $\begin{array}{l}\text { Ö5:Beni tedirgin hissettiriyor, Başarılı olmama rağmen mülakatı kazanma konusunda } \\
\text { endişelerim var. } \\
\text { Ö148: Tedirgin hissediyorum. Çünkü alanında bir yere geliyorsun, emek veriyorsun. Mezun } \\
\text { olup KPSS'ye giriyorsun. Her şeyi aşıyorsun. Mülakat uygulaması karşına çıkıyor. Ya } \\
\text { elenirsem ya olmazsa tedirginliği var. Alan bilgimin dışında beni neye göre } \\
\text { değerlendirecekler sorusu beni kaygılandırıyor. }\end{array}$ \\
\hline - $\quad$ Belirsizlik & $\begin{array}{l}\text { Ö2:Öncelikle sorular nasıl, nereden gelecek net değil, belirsiz olması ve çevremde } \\
\text { girenlerden duyduklarım beni çok etkiliyor. } \\
\text { Ö37: Mülakata çağrılıp çağrılmayacağım belli olmadığı için bir şey hissedemiyorum. }\end{array}$ \\
\hline Adaletsizlik & $\begin{array}{l}\text { Ö4:Gergin, stresli ve adaletsiz bir mülakat olacağını düşündüğüm için iyi hissetmiyorum. } \\
\text { Ö6:Kötü, hakkım yenileceği endişesi içindeyim. } \\
\text { Ö18:Kötü hissettiriyor çünkü ne kadar p121 puanından yüksek alırsam alayım, mülakat } \\
\text { puanı sonucu atamalar yapılıyor. KPSS puanı değerlendirmede etkisiz olduğundan haksızlık } \\
\text { olduğunu düşünüyorum. }\end{array}$ \\
\hline $\begin{array}{l}\text { - Umutsuzluk ve } \\
\text { kaygı }\end{array}$ & $\begin{array}{l}\text { Ö10:KPSS'de başarılı olsam bile mülakatın beni zorlayacağını bildiğim için güvensiz ve } \\
\text { umutsuz hissediyorum. } \\
\text { Ö62:Umutsuz ve gelecek kaygısı yaşayan biri gibiyim. }\end{array}$ \\
\hline
\end{tabular}

Tablo 7 incelendiğinde katılımcıların büyük çoğunluğu (\%91), mülakata girecek olmalarının kendilerinde tedirginlik, umutsuzluk, belirsizlik ve adaletsizlik duyguları yarattığını belirtmiştir.

Tablo 8

Katılımcıların bu sürece nasıl hazırlandıklarına ilişkin görüşlerinin dağılımı

\begin{tabular}{lcc}
\hline Tema & f & $\%$ \\
\hline Hazırlık yapıyor & 100 & 51 \\
Dershane - (12) & & 49 \\
Bireysel - (88) & 98 & 100 \\
\hline Hazırlık Yapmıyor & 198 & \\
\hline Toplam & & \\
\hline
\end{tabular}

Tablo 8 incelendiğinde katılımcıların (\%51), mülakata (çoğunlukla bireysel) hazırlanırken, diğer yarısının ise (\%49) her hangi bir hazırlık içerisinde olmadığı anlaşılmaktadır.

\section{Tablo 9}

Öğretmen atamada, aday belirlemede dikkate alınması önerilen uygulamalara ilişkin katılımcı görüşlerinin dağılımı

\begin{tabular}{|c|c|c|}
\hline Uygulamalar & $f$ & $\%$ \\
\hline Staj Notu & 160 & 84 \\
\hline Kişilik Testleri & 152 & 83 \\
\hline KPSS Puanı & 159 & 83 \\
\hline Diploma Notu & 119 & 61 \\
\hline Mülakat & 112 & 57 \\
\hline Referans Mektubu & 85 & 46 \\
\hline
\end{tabular}


Tablo 9'a göre, katılımcılar, öğretmen adaylarını belirlemede staj notlarının, kişilik testleri ve KPSS puanının etkisinin daha yüksek (\%83-84); mülakat (\%57) ve referans (\%46) mektupları uygulamasının etkisinin daha düşük olması gerektiği görüşündedirler

\section{Tablo 10}

Mülakat uygulamasına yönelik metaforların temalarına göre dağılımı

\begin{tabular}{|c|c|c|}
\hline Tema & Metafor & Gerekçe \\
\hline \multirow{7}{*}{$\begin{array}{l}\text { Adil olmayan seçim } \\
\text { süreci } \\
(f=65 ; \% 35,8)\end{array}$} & Hücre zarı & Seçici geçirgen, işine gelenleri almak için mülakat çok ideal. \\
\hline & Metafor & Sorular sorarak başka bir şeyi anlamak istiyorlar. \\
\hline & Muz kabuğu & Torpili olmayanların ayağı kaydırılmaya çalışılıyor. \\
\hline & Hileli tombala torbası & $\begin{array}{l}\text { Önceden belirlenmiş ya da torpilli olarak kendilerine uygun } \\
\text { kişilerin seçildiği ve diğerlerinin hakkının yendiği bir } \\
\text { uygulama. }\end{array}$ \\
\hline & Tiyatro & İstediğini oynatır, istediğini oynatmaz. \\
\hline & Yarışma programı & $\begin{array}{l}\text { İnsanları saçma sapan ölçütlere göre kıyaslayıp sübjektif } \\
\text { şekilde seçiyorlar. }\end{array}$ \\
\hline & $\begin{array}{l}1984 \text { romanındaki düşünce } \\
\text { bakanlığı }\end{array}$ & $\begin{array}{l}\text { Mülakatta düşüncelerimi ve geçmişimizi tarayıp öğrenmeye } \\
\text { çalıssıyorlar. }\end{array}$ \\
\hline \multirow{7}{*}{$\begin{array}{l}\text { Belirsizliklerle dolu } \\
\text { bir uygulama } \\
(f=58, \% 31,8,)\end{array}$} & Ağaca & $\begin{array}{l}\text { Ya gölgesine sığınıp bundan faydalanırsın ya da üstüne } \\
\text { devrilir felaket olur }\end{array}$ \\
\hline & Pazardaki meyve tezgahı & İyi meyve seçtim diyorsun eve geldiğinde çürük çıkıyor. \\
\hline & Oyun hamuru & Oynayan kişinin istediği sekli alır \\
\hline & Hamam böceği & Nereye gideceği, ne sonuç çıkacağı belli değil. \\
\hline & Bukalemun & Jürinin niyetine göre durum değişiyor. \\
\hline & Dış kapının dış mandalı & $\begin{array}{l}\text { İçerisiyle alakası yok, okul deneyimi, ders notları, öğretmenlik } \\
\text { becerisini yeterince ölçebileceğini düşünmüyorum. }\end{array}$ \\
\hline & Pandoranın kutusu & İçinden ne çıkacağı belli değil. \\
\hline \multirow{4}{*}{$\begin{array}{l}\text { Amacına uygun } \\
\text { kullanıldığında } \\
\text { yararlı bir } \\
\text { uygulama } \\
(\mathrm{f}=32, \% 17,6)\end{array}$} & Balık yetiştiriciliği & $\begin{array}{l}\text { Verdiğin yem ne kadar kaliteli ise hasat ettiğin balıkta o } \\
\text { kadar kaliteli olur. }\end{array}$ \\
\hline & Araba & Doğru kullanılmazsa her şey mahvolur. \\
\hline & Ayna & Bir nevi ayna karşısında kendi yeterliliklerimizi ölçtürüyoruz \\
\hline & Elek & Doğru kişileri ayıklarsa yararlı olabilir. \\
\hline \multirow{3}{*}{$\begin{array}{l}\text { Aşılması gerekli, } \\
\text { zorunlu bir süreç } \\
(\mathrm{f}=27, \% 14,8)\end{array}$} & Sırat köprüsü & Geçtiğinizde huzura eriyorsunuz. \\
\hline & Duvar & Atamalar için bir engeldir, onu geçmeden atanamayız. \\
\hline & Kansere & Teslim olmayıp aşılması gerekli. \\
\hline
\end{tabular}

Katılımcıların öğretmenlik mülakat uygulamasına ilişkin geliştirdikleri 182 metafor, 4 temada toplanmıştır. Temalar, 'adil olmayan seçim süreci' $(f=65 ; \% 35,8)$; 'belirsizliklerle dolu bir uygulama', $(f=58, \% 31,8)$; 'amacına uygun kullanıldığında yararlı bir uygulama', $(f=32, \% 17,6)$ ve 'aşılması gerekli, zorunlu bir süreç', $(f=27, \% 14,8)$ başlıkları altında toplanmıştır.

\section{SONUÇ, TARTIŞMA VE ÖNERILER}

Sonuçlar şöyle özetlenebilir: Sözleşmeli öğretmenlik mülakat soruları, KPSS ve ÖABT sınavlarındaki (kişisel ve meslekî değerler; program-içerik bilgisi ve öğretme-öğrenme süreci) yeterlik alanlarını yoklayıcı niteliktedir. Mülakat yönergesindeki 'bir konuyu kavrama, yorumlama, ikna yeteneği, temsil yeterliği, teknolojideki gelişmeleri izleme' gibi bir sınıflama, sorular dikkate alındığında, sadece teknolojik gelişmeleri izleme ve uyarlama ölçütüne yönelik soruların amacına uygun olduğunu, diğer ölçütlerin iç içe geçtiği ve komisyon üyelerine puanlamayı zorlaştırdığı sonucuna varılmıştır. Bazı soruların ise öğretmenlik mesleği yeterlikleri ile doğrudan ilgisi olmayan alanları yoklamaya yönelik olduğu görülmektedir. Öğretmen adaylarının üçte ikisi, mülakatın olmasını ancak mülakatla yoklanacak yeterliklerin, diğer sınav türleri ile de ölçülebilecek yeterliklerden farklı olmasını ve komisyon üyelerinin bu alanda yetkin olmaları 
gerektiği; mülakata girecek olmanın yoğun bir kaygı uyandırdığı ve uygulamanın bu haliyle adil olmadığı yönünde görüş bildirmişlerdir.

Öğretmenlerin istihdamında gelinen aşamada genel kültür, eğitim bilimleri ve öğretmenlik alan bilgisi testlerinin yanı sıra yürütülen mülakat uygulamalarının amacı, mülakatlar ile ölçülmesi uygun özellikleri yoklayarak, nitelikli öğretmenleri okullarla buluşturmak olmalıdır. Alanyazında (Caruth, Caruth ve Pane, 2008), yapılandııımış mülakat sorularının, adayların iş yaşamında (örneğin sınıflarda) karşılaşacakları olası sorunlara karşı tepkileri ölçmede, alandaki deneyimlerini (örneğin staj, ücretli öğretmenlik, özel okullarda çalışma geçmişi, katıldığı seminerler, lisansüstü eğitim alıp almama vb.) saptamada, bir konuyu etkili biçimde açıklama (kavramları, yaklaşımları, kuramları) ve sunma (öğretimsel teknikler, materyaller) becerilerini sergilemede kullanıldığı; yapılandııımamış mülakat soruları üzerinden (Moscoso ve Salgado, 2008) ise öğretmenlik mesleğine yönelik tutumu (örneğin mesleği tercih nedeni, farkındalık düzeyi, kariyer planının olup olmaması) belirlemeye kadar bir dizi bilgi, beceri, tutum, eğilim gibi alanlarda düzey ve yeterlik saptamada kullanıldığı görülmektedir. Burada sorunun mülakatın kendisinden ziyade uygulama biçiminden kaynaklandığı anlaşılmaktadır. Anderson (2003), yaptığı alanyazın taraması sonuçlarına dayalı olarak, mülakat yoluyla işgören alımlarında en sık karşılaşılan sorunları şöyle sıralamaktadır: Kuramdan uzak bir yaklaşım, seçme sonucunun uzun vadede etkilerini dikkate almayan, daha çok o ana odaklanan yaklaşımlar, adaya aşırı korumacı yaklaşımlar ve araya rastgele serpiştirilmiş izlenimi veren ayırt edici soruların varlığı.

Mülakat uygulaması, testlerin dışında ölçülebilecek nitelikleri belirlemede işe koşulması durumunda, diğer ölçme tekniklerinin (testler, açık uçlu sorular, senaryolara dayalı sorular, uygulamaya dayalı ölçümler vb.) tamamlayıcısı olarak oldukça etkili bir ölçme uygulaması olabilir. Bu noktada mülakatların, bir sınav türü olan sözlü sınavlardan içerik ve uygulama olarak farklılaşmasında yarar vardır. Nitelikli öğretmenleri belirlerken, ölçülmek istenen özellikler burada önem taşımaktadır. Söz konusu özellikleri saptamaya yönelik sorular, bilişsel alanın bilgi boyutu ile sınırlandırılmamalıdır. Bu araştırmanın bulgularına göre katılımcıların önemli bir kısmı, mülakat uygulamasına karşı güvensizlik içerisindedir. Amstrong ve Taylor (2014), işe almak amacıyla yapılan mülakatlarda, yaratılan samimi ortamın, soruların tutarlılı̆ını etkilediği ve yanıtları değerlendirmede olumlu etkisinin bulunduğu; Collins, Lincoln ve Frank (2002) tarafından yapılan araştırmanın bulguları ise mülakata başlarken dostça davranışlar sergileyen mülakatçıların, tarafsız ve sert davranışlar sergileyenlere göre daha iyi sonuçlar aldığını göstermektedir. Bu sonuçlar, tercih edilen mülakatın türü kadar, jürinin mülakat sırasındaki tavrının ve yetkinliğinin, mülakatın amacına ulaşmasında etkili olduğunu göstermektedir. Olumlu yönlerine karşın, şeffaflık ilkesinin yeterince dikkate alınmaması, örneğin mülakat uygulamasının kayıt altına alınmaması, soruların açıklanmaması, aydınlatıcı açıklamaların yapılmayışı vb. (Tonbul, 2017); mülakata alınacak birey ve grupların sürece yeterince hazırlanmaması, uygulayanların ve tabi olanların mülakatın amacına ilişkin farkı yorumlar yapması ya da komisyon üyelerinin yetersizlikleri veya bazı adaylara karşı oluşan önyargılar (Insan Kaynakları Yönetimi, 2017), mülakatlara duyulan güveni azaltabilmektedir.

Araştırmanın bulguları ve alan yazın taraması dikkate alınarak geliştirilen öneriler aşağıda verilmektedir.

MEB Mülakat Değerlendirme Formu'nda yer alan değerlendirme göstergeleri gözden geçirilebilir. Sorular, MEB tarafından yayımlanan "Öğretmen Yeterlikleri" (6 temel alan, 31 alt yeterlik ve 233 performans göstergesi) ile örtüştürülebilir. Öğretmenlik mesleğine yönelik tutumu ölçmeye ve öğretim süreçlerinin gerektirdiği becerileri yoklamaya yönelik sorular ve uygulamalar dikkate alınmalıdır. Mülakat uygulaması, öğretmen adaylarının iletişim becerilerini, düşüncelerini organize etme yeterliklerini, öğrenci, veli ve meslektaşlar açısından ortaya çıkabilecek sorunları çözme kapasitelerini; konu, sorun, senaryo veya kazanım temelli ders deseni oluşturma ve mesleğin gerektirdiği değerler gibi mülakat tekniği ile ölçmeye uygun niteliklerin ölçülmesinde tercih edilmelidir. Bilişsel alandaki soruların üst düzey öğrenme kazanımlarını 
(analiz, sentez, değerlendirme vb.) yoklayacak nitelikte yapılandırılması daha uygun olacaktır. Başka amaçları ölçtüğünü düşündürtecek soruların sorulmaması gerekir.

Öğretmen istihdamında mülakata niçin yer verildiği, dünyadaki başka uygulama örnekleri, araştırma sonuçlarına ve raporlara dayalı olarak MEB tarafından açıklanmalıdır. Eğitim fakültelerinde bu konu tartışılmalı, öğretmen adaylarında yoklanacak nitelikler eğitim programlarında yer almalı, derslerde ve staj uygulamalarında bu niteliklerin geliştirilmesine özen gösterilmelidir.

Mülakat, KPSS'den yüz alan bireyle, mülakata çağrılan en düşük puanlı bireyi aynı düzlemde yarıştırmaktadır. KPSS'de 100 alan birey bu sistemde elenebilirken, 60 ile mülakata çağrılan aday atanabilmektedir. KPSS ve ÖABT puanları, öğrencinin akademik okul başarısı ve staj notları gibi kriterler de belirli bir yüzde ile değerlendirmeye dâhil edilebilir. Başka hangi değerlendirme göstergelerinin işe koşulabileceği araştırılabilir.

Uygulamaya karşı bir güvensizlik vardır. MEB, mülakat uygulamalarını daha şeffaf hale getirebilir. Mülakat komisyonlarında görev alacak kişilerin hangi yöntemle belirleneceği, bu üyelerin kimlerden (deneyimli öğretmenler, müfettişler, okul yöneticileri, akademisyenler, vb.) oluşacağı, adaylardan beklentiler, çıkmış soru örnekleri, katılımcılarla yapılan röportajlar, kamera uygulaması ve bu alanda yapılan araştırma sonuçlarını kamuoyu ile paylaşma gibi uygulamalara gidilebilir.

Komisyon üyelerinin nasıl bir eğitimden geçirileceği ile ilgili araştırma yapılabilir. Bu araştırma, mülakat deneyimi yaşamış adayları, komisyonlarda görevli kişileri, öğretim elemanlarını da kapsayacak biçimde genişletilebilir. Mülakat uygulamalarının, nitelikli adayları seçmede etkisini araştırmaya yönelik boylamsal araştırmalar yapılabilir.

\section{Kaynaklar}

Anderson, N. (2003) Applicant and recruiter reactions to new technology in selection: A critical review and agenda for future research. International Journal of Selection and Assessment 11(2/3), 121-136.

Armstrong, M.\&Taylor, S. (2014) Armstrong's handbook of human resource management practıce. Kogan Cage Publishions.

Aybek, B. (2007) Eleştirel düşünmenin öğretiminde öğretmenin rolü. Üniversite ve Toplum 7(2),1-7.

Bayrak, Ç. (1990). Eğitim yüksekokullarında örgütsel değişme. Yayımlanmamış Doktora Tezi, Hacettepe Üniversitesi Sosyal Bilimler Enstitüsü, Ankara.

Bursalıoğlu, Z. (1994). Okul yönetiminde yeni yapı ve davranış. Ankara: Pegem Yayınları.

Byrnes, D., Kiger, G., \& Shechtman, Z. (2003). Evaluating the use of group interviews to select students into teacher-education programs. Journal of Teacher Education. 54(2), 163-173.

Caruth, D.,L., Caruth, G.D.\&Pane S.S. (2008) Staffing the Contemporary Organization A Guide to Planning, Recruiting, and Selecting for Human Resource Professionals, 3rd Edition. ABC-CLIO.

Celep, C. (2008) Sınıf yönetiminde kuram ve uygulama. Ankara: Anı Yayıncılık.

Collins, R.,Lincoln, R.\&Frank, M.,G. (2002).The effect of rapport in forensic interviewing. Psychiatry, Psychology and the Law, 9(1), 69-78.

Çetin, C.\& Arslan, M.L. (2014) Mülakat: Teori, süreç ve ilkeler. İstanbul: Beta Yayıncılık.

Çetin, C.,Arslan, M.L. \& Dinç, E.(2015) Insan kaynakları yönetimi. İstanbul: Beta Yayıncılık.

Çınar, İ. (2005) İnsan kaynağını geliştirme bağlamında değişim yönetimi. Ege Eğitim Dergisi (6) 1, 81-93.

Demirel, Ö. (1992). A curriculum model for teacher education in europe". Amsterdam: New Prospects for Teacher Education in Europe II. 31 - 40. 
Dursunluoğlu, H. (2003) Cumhuriyet döneminde ilköğretime öğretmen yetiştirmenin tarihi gelişimi. Milli Eğitim Dergisi, 160. [Online]: https://dhgm.meb.gov.tr/yayimlar/dergiler/Milli_Egitim_Dergisi/160/dursunoglu.htm (26.07.2017)

Eğitim Bir Sen (2016) [Online]: http://tekirdag.egitimbirsen.org.tr/manset/1927/sozlesmeli-ogretmenliksorunlara-mulakat-adaletsizlige-yol-aciyor- (28.07.2017)

Erkan, M. \&Erdoğan, O. (2017) Işste mülakat. Ankara: Elma Yayınevi.

EURYDICE (2006)- The information network on education in europe. http://www.mizs.gov.si/fileadmin/mizs.gov.si/pageuploads/eurydice/splosno/20yearsEN.pdf. (24.09.2017).

George, P. ve Kathryne, M. S. (1996). An examination of admission criteria to programs of teacher education. Paper presented at the annual meeting of the Mid-Western Educational Research Association. (ED 401 278).

Getzels. J. W. \& Guba, E. G. (1957) "Social Behavior and the Administrative F ocess.". School Review. 65 (4): 423-441,1957.

Glesne, C.\& Peshkin, A. (1992). Becoming qualitative researchers an introduction. London: Longman Group Ltd.

Güçlü, A. (2016) Mülakat fırtınası. Milliyet Gazetesi, 1.16.2016. [Online]: http://www.milliyet.com.tr/yazarlar/abbas-guclu/mulakat-firtinasi--2320011/(18.09.2017).

Hoy,W.K..\& Miskel, C.G. (2001) Educational administration: Thery, research and practise. 6. edition, McGraw Hill.

İnsan Kaynakları Yönetimi (2017) [Online]: http://slideplayer.biz.tr/slide/1890916/ (22.09.2017)

Jacobowitz,T., Delorenzo, L. ve Adirim, M. (2000). Incorporating concerns for diversity and social justice in admissions decisions. A paper presented at the annual meeting of the American Educational Research Association. (ED 477735).

Kador, J. (2006) The manager's book of questions : 751 Great Interview Questions for hiring the right person.New York: McGrill Hill.

MEB İnsan Kaynakları (2017) Sayısal veriler. [Online]: http://ikgm.meb.gov.tr/sayisal_veriler.asp?ID=207

MEB Mülakat Değerlendirme Formu (2016) [Online]: http://www.mebpersonel.com/haber/mulakat-sozlusinavlarda-bu-kriterlere-gore-puan-verilecek-h212121.html. (18.10.2017).

MEB Şura Kararları (2010). 1. Milli Eğitim Şurası Kararları. [Online]: https://ttkb.meb.gov.tr/meb_iys_dosyalar/2017_09/29165619_17_sura.pdf (13.09.2017).

Moscoso, S.\&Salgado J.F.(2004) Dark side" Personality styles as predictors of task, contextual, and job performance. International Journal of Selection and Assessment. 12(4) 253-362.

Memurlar.net (2017) Sözleşmeli öğretmenlik için oluşan minimum puanlar [Online]: http://www.memurlar.net/haber/612130/sozlesmeli-ogretmenlik-icin-olusan-minimumpuanlar.html. (13.09.2017).

Miles, J.A. (2016) Yönetim ve organizasyon kuramları. Çev. ed. Mustafa Polat, Korhan Arun. Ankara: Nobek Yayıncilık.

Muller, G. D.(1981). Teacher selection: a response. Educational Leadership. 38(6), 492-4.

Okçabol, R. (2004) Öğrenci, öğretmen, öğretmen adayı ve öğretim elemanı gözüyle öğretmen yetiştirme. XIII. Ulusal Eğitim Bilimleri Kurultayı, 6-9 Temmuz 2004 İnönü Üniversitesi, Eğitim Fakültesi, Malatya.

Öğretmenlik Mesleği Genel Yeterlikleri (2006) [Online]: http://otmg.meb.gov.tr/YetGenel.html. (28 07.2017).

ÖSYM (2016) KPSS öğretmenlik (ÖABT) aday sayıları. [Online]: http://dokuman.osym.gov.tr/pdfdokuman/2016/KPSS/OABT/OABTSonucSayisalBilgiler02092016.pdf . (01.08.2017).

Pellicer, L. O. (1981). Improved teacher selection with the structured interview. Educational Leadership. 38(6), 492-94. 
Patten, M.L. (2010). Proposing empirical research: A guide to the fundamentals. Glendale, CA: Pyrczak Publishing.

Sağlar, F. (2017) Öğretmenlere 'mülakat' soruları, ya da tanıdık bir 'ayıklama yöntemi! Bir Gün Gazetesi, 04.10.2016. [Online]: http://www.birgun.net/haber-detay/ogretmenlere-mulakat-sorulari-ya-datanidik-bir-ayiklama-yontemi-130271.html. (28 07.2017)

Senemoğlu, N. (2003). Türkiye'de sını öğretmeni yetiştirme uygulamaları, sorunları, öneriler. Burdur Eğitim Fakültesi Dergisi, 5, 154-193.

Shechtman, Z. \& Godfried, L. (1993) Assessing the performance and personal traits of teacher education students by a group assessment procedure: a study of concurrent and construct validity. Journal of Teacher Education, 44(2), 130-138.

Shechtman, Z. (1992). A group assessment procedure as a predictor of on-the-job teacher performance. The Journal of Applied Psychology. 77, 383-387.

Shenton, A. K. (2004). Strategies for ensuring trustworthiness in qualitative research projects. Education for Information, 22, 63-75.

Swaim, R. (2011) Bir strateji ustası Peter Drucker. 2. Basım, Çev. Ümit Şensoy. İstanbul, Türkiye İş Bankası Yayınları.

Şimşek, H. (2003). Ortaöğretim alan öğretmenliği tezsiz yüksek lisans programına devam eden öğrencilerin öğretmenlik mesleğine yönelik tutumları. Yüzüncü Yı Üniversitesi, Elektronik Eğitim Fakültesi Dergisi, 2(1), 1-25.

Tonbul, Y (2017) Sosyal bilimler enstitülerinin lisansüstü eğitimin niteliğini artırmadaki rolü. Yükseköğretim ve Bilim Dergisi. 7 (1), 150-162.

Toprakçı, E.\& Altunay, E. (2015). Anılarla öğretmenlik. Ankara: Pegem Akademi Yayıncılık.

Türkoğlu, A. (1988). Eğitim yüksekokulları program uygulamalarında karşılaşılan sorunlar. Çukurova Üniversitesi Eğitim Fakültesi Yayınları, No: 1.

Ülkar, E. /(2017) Sendikalar eğitim öğretim yılını değerlendirdi: Sözleşmeli öğretmenlik kaldırılmalı. [Online]: http://www.hurriyet.com.tr/egitim/sozlesmeli-ogretmenlik-kaldirilmali-40860870

Yasseen B., M. B. (2010) The effect of teachers' behavior on students' behavior in the classroom. International Forum of Teaching and Studies. 6(1), 48-57.

Yıldırım, A. \& Şimşek, H. (2016). Sosyal bilimlerde nitel araştırma yöntemleri. (10. Baskı). Ankara: Seçkin Yayıncılık. 


\section{Investigation of the Questions in the Contracted Teacher Interview According to the Teacher Candidate's Opinions}

\author{
Assoc.Prof.Dr. Yılmaz TONBUL \\ Ege University-Turkey \\ yilmaz.tonbul@ege.edu.t
}

\author{
Yunus AĞAÇDiKEN(MA) \\ Ege University - Turkey \\ yunus.agacdiken@gmail.com
}

\begin{abstract}
The aim of this study is to evaluate the interview application of teacher recruitment by way of reached questions and the opinions of teacher candidates. The research is designed as a phenomonolical study based on qualitative data. The research group consist of 198 students, who are studying at the last class of different departments at the faculty of education in Ege University in 2016-2017 semester and participate in pedagogical certificate program to become a teacher. The data were collected through the analyzing of reached interview questions and the structured interview form developed by the researchers. Content analyzing techniques were used at data analyzing. The findings show that the 'Teacher Profession General Competencies' were not taken into consideration enough according to the interview questions. The announced evaluation criteria from the Ministry of Education are insufficient to evaluate the qualifications which are appropriate for interview. The teacher candidates find not only the interview necessary to recruit qualitative teachers but also the contribution point of the interview
\end{abstract}

Keywords: Interview technique, teacher recruitment, teacher candidates

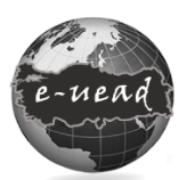

E-International Journal of Educational Research, Vol: 9, No: 2, 2018, pp. 46-63

DOI: 10.19160/ijer.395554

\section{Suggested Citation:}

Tonbul,Y. \&. Ağaçdiken, Y. (2018). Investigation of the Questions in the Contracted Teacher Interview According to the Teacher Candidate's Opinions, E-International Journal of Educational Research, Vol: 9, No: 2, 2018, pp. 46-63, DOI: 10.19160/ijer.395554 


\section{EXTENDED ABSTRACT}

Introduction: Especially in the private sector but in some parts of public institution's too, have interviews been the main method of recruiter selection for a long time. Beginning from 2016 with the interview exam, contracted teachers have been employed for the first time as well as public test (general culture and educational sciences) and subject test (ex. chemistry, history etc.). Interviews that are one of the tools for recruiting show differences according to their goals, configuration levels, in which sector they are enforced, used tools and the quality of the questions' (Çetin \& Arslan, 2014). Interviews in employee selection procedures can be applied by in general as face-to-face meeting, panel group, work mates group, sequential interview, evaluation center and phone interviews (Human Resources Management, 2017). Anderson argued (2003) telephone-based or video-based interviews, and yet interviews in virtual environment, scenarios composed of real class environments, situational judgement tests are used in different sectors as new technology in employee selection. When considering interview application as a tool, what will be evaluated in the interview and the type of it become the main topic. Shechtman (1992) stated the variable that affects the classroom performance of teachers' include affective and psychomotor dimension like verbal expression skills, personality characteristics and leadership features. Byrnes, Kiger and Shechtman (2003) also Shechtman and Godfried's (1993), research findings show, that interview as group focused evaluation type with them the teacher candidates psychomotor and affective behaviors evaluated, predict the classroom performance of teachers better than the academic criteria. Different question types which are used professionally of the interview commission member like Ice breaker and basic questions, behavior, ethic, relevancy, efficiency, intelligence and closure questions (Kador, 2016) or hypothesis questions, ability, motivation, carrier, interest questions (Armstrong and Taylor, 2014) will increase the validity of the interview's.

In consideration of the role of teacher's in the educational system and their responsibilities, it is very important to carry out the interview process professionally and according to their goals. As the application is very new, there has not arisen a literature in Turkey. This research aims to reveal the problems of the interview application in selection teacher candidates and contributes to the literature also gives advices to the application.

Method: The research is designed as a phenomenological study based on qualitative data. The study group determinates at using oriented sampling methods easy accessible and criteria sampling techniques. The research group consists of 198 students, who are studying at the last class in different departments at the faculty of education in Ege University in 2016-7 semester and participate at pedagogical certificate program to become a teacher. At the analysis of interview questions, the Teacher Profession General Competencies' and the announced evaluation criteria from the Ministry of Education are considered. The data collected through the analyzing of reached interview questions and the interview tool developed by the researchers. The data from the sampling was collected through a survey developed by the researchers. Content analyzing techniques were used at all data's analyzing.

Findings: The 'Teacher Profession General Competencies' were not taken into consideration enough according to the interview questions. The announced evaluation criteria from the Ministry of Education are insufficient to evaluate the qualifications, which are appropriate for interview. The goals of some questions were not in relation with teachers' features, which connected with the profession. The teacher candidates find the interview as necessary as to recruit qualitative teachers but the contribution point of interviews is high. The interview questions should measure psychomotor skills beside cognitive dimension. The interview commission members should have authority in the teacher profession and interview techniques. The application has a negative impression on the candidates and causes anxiety.

Conclusions: The interview application, used as an evaluation tool, beyond the features that can measured with other types of assessment techniques (test, open-ended question, virtual reality 
scenarios, application based evaluation, etc.) could be very effective as a complement tool. According to the findings, an important part of the participants is in lack of confidence about the interview application. The data show that the reason of this problem occurs not from the interview self-technique rather than from the management process of this application. Anderson (2003) argued four major criticisms of the extent applicant reactions research base are noted: its non-theoretical orientation, a short-termist concentration upon reactions level outcomes, an over-reliance on students as surrogates, and a patchiness of coverage of crucial research questions. Armstrong \& Taylor (2014) argued that the sincere atmosphere during the interview process affects the consistency of questions and the positive effect of evaluation to the answers.

Suggestions: The interview has to apply to evaluate teacher candidate's communication skills, the ability to organize ideas and thoughts, their capacity of losing the problems those occur between student's, parent's and colleague's; develop a topic, problem, scenario or goal oriented lesson pattern. Suspicious questions should be avoided. The qualifications expected at the interview, take part in the teacher education programs and should develop trough instructional and internship activities. The use and efficiency of new technology (computer-based testing, internet-based recruitment and candidate assessment, telephone-based and video-based interviews) can research. This research can be extended with interview experienced teacher candidates, commission member and academicians. 